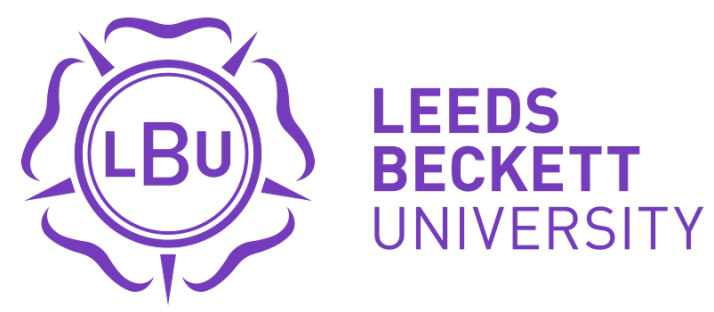

Citation:

Ajayi, SO and Oyedele, LO and Jaiyeoba, B and Kadiri, K and David, SA (2016) Are sustainable buildings healthy? An investigation of lifecycle relationship between building sustainability and its environmental health impacts. World Journal of Science, Technology and Sustainable Development, 13 (3). pp. 190-204. ISSN 2042-5945 DOI: https://doi.org/10.1108/wjstsd-01-2016-0015

Link to Leeds Beckett Repository record:

https://eprints.leedsbeckett.ac.uk/id/eprint/3222/

Document Version:

Article (Accepted Version)

The aim of the Leeds Beckett Repository is to provide open access to our research, as required by funder policies and permitted by publishers and copyright law.

The Leeds Beckett repository holds a wide range of publications, each of which has been checked for copyright and the relevant embargo period has been applied by the Research Services team.

We operate on a standard take-down policy. If you are the author or publisher of an output and you would like it removed from the repository, please contact us and we will investigate on a case-by-case basis.

Each thesis in the repository has been cleared where necessary by the author for third party copyright. If you would like a thesis to be removed from the repository or believe there is an issue with copyright, please contact us on openaccess@leedsbeckett.ac.uk and we will investigate on a case-by-case basis. 


\title{
Are Sustainable Buildings Healthy? An Investigation of Lifecycle Relationship between Building Sustainability and Its Environmental Health Impacts.
}

\begin{abstract}
Purpose: There have been speculations as to whether environmental friendly buildings are always healthy. Using Life Cycle Assessment (LCA) methodology, this study investigates lifecycle relationship between building sustainability and its environmental health impacts Methodology: In order to achieve this, a block of classroom was modelled with the aid of Revit software, and its lifecycle Global Warming Potential (GWP) and human health impacts were analysed using Green Building Studio and Athena Impact Estimator tools. Sensitivity analyses of the block of classrooms were then carried out by varying the building materials and energy use pattern of the original typology. The lifecycle assessment was performed for seven alternative typologies that were achieved through variation in the building materials and energy use patterns.
\end{abstract}

Findings: For all the eight building typologies, the study shows a direct relationship between global warming potentials and human health impacts. This confirms that the more sustainable a building, the less its tendency for having negative health effects on building operatives, occupants and the wider environment. Again, the more green a building in terms of its materials and energy use pattern, the healthier the building becomes.

Limitations: The human health impacts was evaluated by measuring amount of particulate matter (PM2.5) produced by the buildings while environmental impact was evaluated by measuring global warming $(\mathrm{KgCO} 2)$ potentials of the buildings throughout its lifecycle. The study has been based on the impacts of building materials and energy use patterns over the entire lifecycle of the buildings and materials used for construction.

Originality/Value: The study established a positive relationship between global warming potential of building and its human health impacts. Thus, all arguments relating to the relationship between building sustainability and health are laid to rest by the paper.

Keywords: Building and Health; Global Warming; LCA; Sustainability; Environmental Health; Building Lifecycle; Operational impacts; Renewable Technologies. 


\section{Introduction}

As a result of its contribution of substantial portion of $\mathrm{CO}_{2}$ in the atmosphere (Baek et al. 2013), consumption of large mineral resources (Anink et al., 1996) and generation of largest proportion of landfill waste (Oyedele et al., 2014), construction industry has remained under pressure to improve its environmental sustainability. Advocates of environmental sustainability have stressed that apart from emission of obnoxious gases that are capable of damaging the atmosphere (Chau et al., 2007; Guggemos and Horvath, 2005), building activities have significant impacts on resource depletion (Ajayi et al. 2015a). It has often been stated that the achievement of global sustainability agenda and prevention of impending negative environmental impacts depends on how well the construction industry is able to reduce its $\mathrm{CO}_{2}$ emission, virgin materials consumption and waste to landfill (Ajayi et al., 2015a). Owing to these needs, substantial legislative and research efforts have been made to curb waste generation and carbon emission from the industry. Apart from the usual issues around cost, time and quality, sustainability is becoming the fourth dimension for evaluating success of a building design and construction activities (Gangolells et al., 2009). This has led to significant improvement in the sustainability of the construction industry as a result of the use of renewable technologies, innovative materials and low carbon techniques.

Apart from environmental sustainability, the design and method of construction of the built environment have great impacts on human health. It has been argued that "the connection between health and dwelling of the population is one of the most important that exist" (Hood, 2005, p. A317). This means that building design, materials and methods of construction as well as the actual construction process could affect health of the occupants, operatives and general populace over its entire lifecycle. Evidence shows that several diseases, deaths and ultimate damage to the wider environment have been associated with building health and safety hazards (Raw et al., 2001). These are as a result of poor design and construction techniques, improper ventilation system as well as wrong materials and products selection (Ajayi et al., 2014).

Despite its likelihood of affecting human well-being, lifecycle health aspects of the built environment has received less attention. This is unlike issues relating to energy efficiency and environmental sustainability, which has become an important measure of project success. 
This negligence has often been defended with an assumption that reducing global warming potential of built infrastructure could amount to reducing its negative health impacts (Allen et al., 2015). While this claim is becoming the norms of the industry and justification for lack of holistic efforts for improving building health (Poland and Dooris, 2010), there is lack of empirical research substantiating such claim hitherto. Few studies investigating relationship between green buildings and health were only been based on subjective evaluation (Allen et al., 2015). Conversely, it has been suggested that, without adequate measures, increasing consciousness of energy efficiency could be at the expense of the health of building occupants. For instance, Boldi (2014) suggests that naturally ventilated building might contribute to ingestion of polluted outdoor air. This is against the common notion that as naturally ventilated buildings are energy efficient and more sustainable, they are equally meant to be healthier (Redlich et al., 1997).

With the growing controversies and unsubstantiated claims regarding the relationship between building health and building sustainability (Cheshire, 2011), it is important that empirical evidence be provided. In order to understand the impacts of building sustainability on the health of building occupants, operatives and the general environment, this study investigates the relationship between building sustainability and human health impacts of the building. As such, the study seek to test a hypothesis, which claims that the more sustainable a building, the healthier it is. The study fulfils its aim through the following objectives.

1. To evaluate lifecycle environmental impacts of different design typologies

2. To determine whole life human health impacts of buildings across different typologies

3. To establish relationship between environmental and health impacts of building typologies over their entire lifecycle.

The study adopts methodology in Lifecycle Assessment (LCA) to evaluate environmental and health impacts of eight building typologies. The LCA methodology has been adjudged to be the best approach for evaluating impacts of buildings over its entire lifecycle (Khasreen et al. 2009; Guggemos and Horvath, 2005). The results from lifecycle environmental and human health impacts of different design typologies are then compared to establish relationship between sustainability and health. 
As a theoretical insight for this study, the next section review literatures on the concept of sustainability, building health and LCA methodology. Methodological approach employed in the study, which includes description of case study models and analytical process is justified and discussed. Findings of the study are then presented and discussed before culminating the study with implication for practices and conclusion. All arguments relating to the relationship between building sustainability and health are laid to rest by the paper.

\subsection{Lifecycle Environmental and Health Impacts of Buildings}

Apart from its contribution to climate change, among other environmental hazards, building activities is capable of affecting human health (Allen et al., 2015). As a result of this, impacts of indoor environment on employees' productivity, health and well-being is an important subject of public health practice and research. However, apart from the indoor environment, there is a general paucity of literature on the whole life health impacts of buildings. This is albeit the fact that materials manufacturing and transportation, building construction, operation and end of life demotion have the potentials of producing particulate matters capable of affecting human health (Ajayi et al., 2015b). In order to provide a theoretical background for understanding the relationship between lifecycle environmental and health impacts of buildings, this section provides a review of extant literatures. The concept of building sustainability, building health and environmental impacts were clarified before culminating the section with a review of methodological approach to whole building impact analysis.

\subsection{Building Sustainability and Environmental Protection}

The concept of sustainability has remained a top priority on the agenda of government across the world. According to Brundtland commission (1987), sustainability is referred to as "meeting the needs of the present without compromising the ability of future generations to meet their own needs". It is a broad phenomenon that describes the tendency of carrying out activities without depleting mineral resources or causing harmful impacts on the environment. As the construction industry consumes large portion of mineral resources (Anink et al., 1996), the industry has remained under pressure to reduce its consumption of virgin materials and increase its materials reuse. In addition, its contribution of high proportion of landfill waste and emission of $\mathrm{CO}_{2}$, among other gases, has made the industry to 
remain a major target for achieving environmental sustainability (Anderson and Thornback, 2002; Ajayi et al., 2015a). These gaseous emissions is as a result of materials extraction and processing, actual construction processes, building operation and maintenance, as well as end of life demolition and subsequent treatment of building remnants. As such, sustainability has become a key performance indicator for building projects.

Sustainable building is a broad term that describes buildings with minimal impacts on the environment through its location, design, construction, maintenance and demolition. Although there are economic and social dimensions to sustainability (Munasinghe, 2007), significant efforts has been made on the environmental aspects of building sustainability (Ding, 2008). Consequently, buildings environmental performance assessment frameworks have become rife within the construction industry (Cole, 1998). These set of performance assessment tools require that environmental protection, social development and economic development be adequately considered in the location, design, construction, operation and end of life dismantling of the buildings. As a means of minimizing its environmental impacts, buildings are expected to reduce energy and water requirements, use materials with low environmental impacts, reduce materials wastage and take measures to prevent its negative effects on human health.

As a result of its materials production, construction, operation and end of life demolition, several environment impacts could be produced by buildings (Akinade et al., 2015). These impacts categories include global warming, acidification, climate change, human toxicity, ozone depletion and eutrophication, among others (Hamilton et al., 2007). These are usually calculated as an aggregate of emission to air, water and land, resource consumption and energy consumption by the buildings' lifecycle activities. This means that improving buildings' sustainability have tendencies of preventing its impacts on the environment (Khasreen et al., 2009; Ding, 2008). Notwithstanding the understanding that environmental impacts of buildings span from its cradle to grave, operational impacts have been of major concern. Although, evidence suggests that operational stage contributes largest proportion of buildings' lifecycle impacts (Ajayi et al., 2015b; Dodoo et al., 2012), there is need to reduce environmental impacts of other stages of buildings' lifecycle. 


\subsection{Building and Health}

Relationship between buildings and health has remained a subject of literature since the mother of modern day nursing, Florence Nightingale, established that "the connection between health and dwelling of the population is one of the most important that exist" (Hood, 2005, p. A317). This connection became more apparent during the industrial revolution as result of increasing epidemic that was caused by overcrowding and poor sanitary system, among others (Perdue et al., 2003). Recently, it has become more evident that buildings does not only have impacts on occupants' health, it also have capacity of affecting employees' productivity (Allen et al., 2015). This has raised more consciousness about the concept of Sick Building Syndrome (SBS), which describes a situation whereby occupants of building have feelings of ill health and discomforts with such discomfort disappearing after leaving the building. A special report into relationship between health and the built environment, prepared by the LEED-ND core committee, established relationships between buildings and respiratory, mental and cardiovascular health.

Literatures suggests that the impacts of buildings on health could be due to several reasons. For instance, Perdue et al. (2003) suggest buildings' impacts on health is as a result of concentration of toxins, Volatile Organic Compounds (VOCs) or pollutants in the indoor environment. These pollutants are usually from the building materials (Berge, 2009) and their impacts is exacerbated by inadequate airflow within the spaces (Ajayi et al., 2014). Redlich et al. (2007) argue that symptoms of SBS and other building related health issues are usually caused by poor indoor ventilation while Finnegan et al. (1984) and Burge et al. (1987) buttress the claim by suggesting that SBS are usually due to poor Heating, Ventilation and Air Conditioning (HVAC) system. Gunnbjörnsdottir et al. (2003) and Bornehag et al. (2001) similarly established a causative relationship between building dampness and respiratory health of the inhabitants. These confirm that several factors are capable of contributing to health impacts of buildings on its occupants.

Apart from the indoor environment, building materials, construction and operation have tendencies of increasing environmental health problems (Nemry et al., 2010). This is due to concentration of particles in the atmosphere as a result of the buildings. According to Chau et al. (2007), damages to health could be caused by carcinogens, respiratory organics and inorganics, radiation and ozone depletion. Atmospheric concentration of particulate matters 
have also been traced to building materials manufacture, construction processes, building operation and demolition activities (Riley et al., 2002; Guidotti, 2015). As the relationship between particulate matters (PM) and such diseases as bronchitis, asthma and acute pulmonary diseases is established (Athena, 2013), it is clear that health impacts of buildings extend to both indoor and outdoor environment.

\subsection{Whole-life Impacts Analysis of Buildings}

Based on Lifecycle methodology, impact of buildings on the environment ranges from its materials extraction to its end of life. As such, it is important that each of the stages of building lifecycle be adequately considered in order to estimate its holistic impacts. Whole building Lifecycle usually cover five stages, which are raw materials and manufacturing, construction, operation, maintenance, and demolition stages (Wang et al., 2011). As result of simplifications suggested for successful implementation of LCA, some studies neglect one stage or the other. For instance, while carrying out BIM-based LCA of whole building, Wang et al. (2011) neglected demolition stage as a result of its insignificance in reference to Sartori and Hestnes (2007).

The raw material and manufacturing phases encompasses environmental burden as a result of extraction and refinement of the raw material and production process, while construction stage accounts for not only site based construction activities, but also transportation of the materials and workers to the site (Wang et al., 2011; Ramesh et al., 2010). Few studies estimated material transportation as separate stage in the life cycle of whole building (e.g. Scheuer et al., 2003). Several studies also neglected maintenance stages due to level of uncertainty involved (e.g. Adalberth et al., 1997), while many others (e.g. Rossi et al., 2012) neglected transportation stage. Nevertheless, all known studies identified material and manufacturing, construction and operation stages as crucial stages for evaluating impacts of buildings. Stages covered or omitted in each study would therefore be determined by the goal and scope of the study (Optis and Wild, 2009).

Basically, studies investigating environmental impacts of buildings are carried out within the ISO14040 framework for lifecycle assessment. However, combination of LCA tools and other external analysis tools have been used. For instance, Ooteghem and Xu (2012) used ATHENA Impact Estimator for estimating other impacts than operational impacts of the building, while eQUEST assisted in calculating lifecycle operational impacts of the building. 
Ghattas et al., (2013) also employed Eco invent LCA tool based on an argument that it is one of the commonly used LCA data source. Other databases that have been used in various studies include inventory prepared by Japan Building Construction (Baek et al., 2013), Finnish building classification (Wang et al., 2011), Bath University Inventory of Carbon and Energy (ICE) (Hammond and Jones, 2008), and so on. Irrespective of the variation in methods and tools of assessment, studies estimating holistic impacts of buildings are required to be in four phases, which are goal and scope definition, inventory analysis, impact assessment and result interpretation.

\section{Methodology.}

The study aims at comparing health and environmental impacts of buildings. In order to achieve this aim, a case study of a block of classrooms was modelled with the aid of Revit software, with the building detailed at BIM level 2. This section describes the methodological framework, case study model, and the processes used in the study.

\subsection{Lifecycle Analysis Methodological Framework}

The scope of this study is limited to lifecycle evaluation of human health and environmental impacts of a classroom block over a lifecycle duration of 30 years as recommended by Saynajoki et al. (2012). The analysis covered the whole building structure as well as whole life duration, which encompasses material extraction and transportation, manufacturing (regarded as product), construction, operation and replacement, and end of life stages. Inventory analysis of the building was carried out with the aid of Revit software using volume estimates. This was then entered into ATHENA impact estimator tool, which is a LCA software designed to estimate environmental impact of a built facility through the volume of materials used in its construction. As the ATHENA Impact estimator lacks capacity for evaluating operational impacts of a building, the tool was corroborated with Green Building Studio tool, which was used in estimating operational impacts of the building. The unit of operational energy were later converted into such impacts as acidification, global warming potential, etc. by the impact estimator.

Based on the aim of this study, the two major impacts that were assessed in this study were human health impacts and global warming potential (GWP) of the buildings. The health 
impacts was measured in terms of the volume of particulate matters (PM2.5) likely to be present in the air as a result of materials manufacturing, construction, operation and end of life demolition of the buildings. It is suitable for measuring health impacts of building as evidence shows that it is capable of causing such diseases as bronchitis, asthma and acute pulmonary diseases (Ajayi et al., 2014). The GWP was particularly used in measuring environmental impacts, as a study by the UK BRE suggests that it is the most potent of the impacts categories (Hamilton et al., 2007). To enhance comparison of the human health impacts and sustainability of the building, materials specification and energy used pattern were varied across eight cases. Lifecycle impacts of the main case study was then interpreted and compared to alternative cases.

\section{2. $\quad$ Case Studies}

A case study of a block of classroom, with seven-sensibility analyses, was used for the study. The case study is characterised by the following.

\begin{tabular}{ll}
\hline \multicolumn{2}{c}{ Table 1: General characteristics of the case study } \\
\hline Building type: Primary school & Number of floor: 2 \\
Ground Floor area (used for the study): $1319 \mathrm{~m}^{2}$ & First floor area (used for the study): $938 \mathrm{~m}^{2}$ \\
Lighting control: All manual & Green roof area: $258 \mathrm{~m}^{2}$ \\
First floor roof area: $1050 \mathrm{~m}^{2}$ & Low level roof: $183 \mathrm{~m}^{2}$ \\
\hline
\end{tabular}

In order to enhance comparison of the model, materials specification was varied for other three alternatives. This resulted into typologies 2, 3 and 4. As a means of comparing buildings that are based on renewable technology with those based on fossil fuel, amount of energy that could be generated for the building through the use of PV panel was calculated through Green Building Studio (GBS) tool. Parts of energy required for building operation was then substituted with likely output from the PV panels. This resulted into energy efficient alternatives of typologies $1-4$, which are labelled as typologies 1A, 2A, 3A and 4A. Based on the simulated energy use pattern for the building (Figure 1), it was assumed that the PV panels would provide energy for lighting, fans and miscellaneous equipment, while other energy needs would be fulfilled through the use of fossil fuel. For each of the energy efficient alternatives, embodied impacts of the PV panel was added to the overall embodied impacts of the buildings, while operational energy required for lighting, fans and other 
miscellaneous equipment were subtracted from operational impacts of the main typologies (1-4). The embodied value of PV panel was taken at an average value of $60 \mathrm{~g}$ of $\mathrm{CO} 2 / \mathrm{Kwh}$ based on the works of Zhong et al. (2011) and Sherwani et al. (2010. Table 2 presents specific characteristics of each of the typologies.
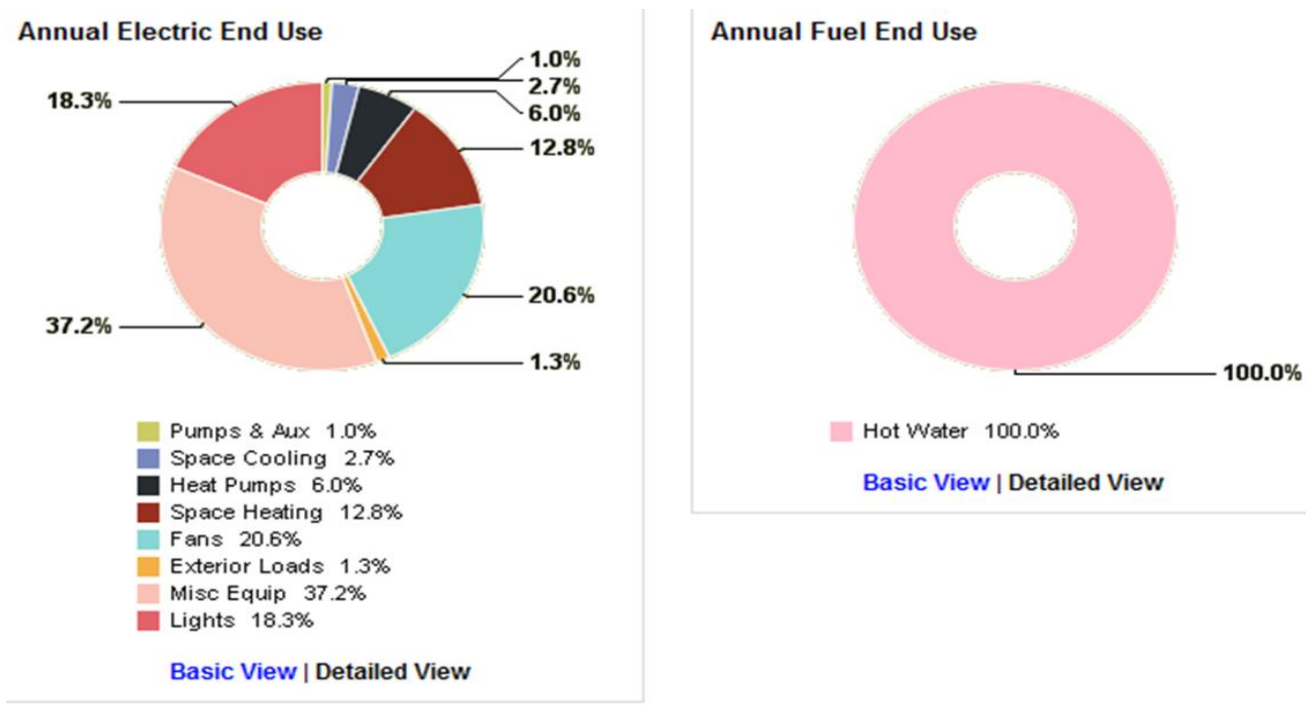

Figure 1: Simulated energy use pattern for the building

\subsection{Process Description}

Figure 2 illustrates the methodological processes involved in carrying out environmental/health impacts analyses for each of the eight case studies.

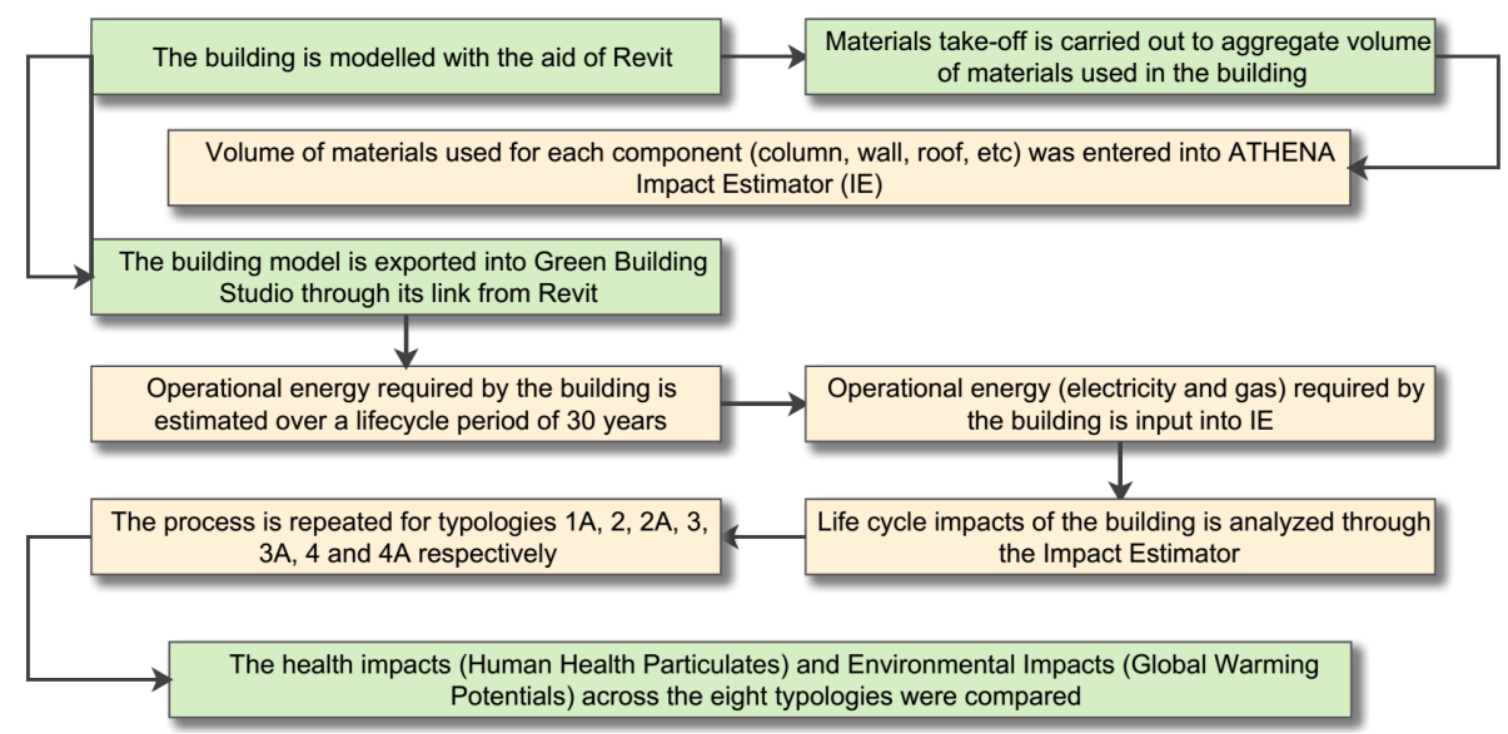

Figure 2: A typical simulation flow pattern 
Table 2: Materials and energy use variation across the typologies

\begin{tabular}{|c|c|}
\hline Building Systems & Specific characteristics of the typologies $(1-4 \mathrm{~A})$ \\
\hline Exterior Walls & $\begin{array}{l}\text { 1. Brick/block cavity wall. } \\
\text { 2. Cladded timber cavity wall filled with cellulose insulation. } \\
\text { 3. ICF with expanded Polystyrene. } \\
\text { 4. Gypframe steel framed wall with polystyrene insulation. }\end{array}$ \\
\hline Interior Walls & $\begin{array}{l}\text { 1. Hardwood structural post as main beam, and glue lamp as secondary frame. } \\
\text { 2. Hardwood structural post as main beam, and glue lamp as secondary frame. } \\
\text { 3. Reinforced Concrete column structure } \\
\text { 4. Steel frame }\end{array}$ \\
\hline Structures & $\begin{array}{l}\text { 1. Hardwood structural post as main beam, and glue lamp as secondary frame. } \\
\text { 2. Hardwood structural post as main beam, and glue lamp as secondary frame. } \\
\text { 3. Reinforced Concrete column structure } \\
\text { 4. Steel frame }\end{array}$ \\
\hline Ground Floor & $\begin{array}{l}\text { 1-3 Timber raised floor insulated with blown cellulose, on CMU structure. } \\
\text { 4. Steel plate raised on CMU, and finished with synthetic resin }\end{array}$ \\
\hline First Floor & $\begin{array}{l}\text { 1. Timber boards with I-section timber frame and resin floor finish } \\
\text { 2. Timber frame and timber board finished with synthetic resin } \\
\text { 3. Precast concrete floor } \\
\text { 4. Gypframe steel flooring }\end{array}$ \\
\hline Windows & $\begin{array}{l}\text { 2. Timber-frame, double-glazed, argon-filled, U-value } 1.55 \mathrm{~W} / \mathrm{m} 2 \mathrm{~K} \\
\text { 1, } 3 \& 4 \text {. Aluminium-frame, double-glazed, argon-filled, U-value } 1.55 \mathrm{~W} / \mathrm{m} 2 \mathrm{~K}\end{array}$ \\
\hline Roofs & $\begin{array}{l}\text { 1. Slate roofing sheet with wood frame } \\
\text { 2. Insulated timber plate flat roof with EPDM cover } \\
\text { 3. Reinforced concrete flat roof with } 40 \% \text { GGBS/recycled aggregate } \\
\text { 4. Insulated steel plate flat roof covered with EPDM }\end{array}$ \\
\hline$H V A C$ & $\begin{array}{l}\text { 1-4. Gas fired boiler, steam from Central Power plant. } \\
\text { 1A, 2A, 3A \& 4A: Renewable source with lower percentage of fossil fuel. }\end{array}$ \\
\hline Electricity & $\begin{array}{l}\text { 1-4. } 100 \% \text { from external regional utility } \\
\text { 1A, 2A, 3A \& 4A: Renewable/non-renewable sources }\end{array}$ \\
\hline Ceiling & All: Suspended gypsum ceiling with steel grid \\
\hline Column & $\begin{array}{l}\text { 1-3. Pressure treated sawn hardwood } \\
\text { 4. Steel column. }\end{array}$ \\
\hline
\end{tabular}

Note: 1 is a typical Brick/block building; 2 is a timber structure; 3 is ICF building and 4 is a steel structure. $1 \mathrm{~A}$, $1 B, 1 C \& 1 \mathrm{D}$ are energy efficient alternatives of $1,2,3 \& 4$ respectively.

\section{Findings and Discussion}

As shown in Table 3, global warming potential of the building varies from one typologies to another. It was evident from the table that building that employed renewable technology (Type 1A, 2A, 3A and 4A) are more environmental friendly compared to the same building that employed fossil fuel for building operation (Type 1, 2, 3 and 4). For instance, while brick/block building (Type 1) will generate $5,207,440 \mathrm{kgCO}_{2}$ over its lifecycle, it will only generate $1,418,467 \mathrm{KgCO}_{2}$ when it employed PV for its electricity, fans and miscellaneous equipment (Type 1A). This is in line with earlier studies, which posit that the more energy 
efficient a building, the less its impacts on the environment (Dodoo et al., 2012). Similarly, the table shows that operational stage of a building could contribute about $80 \%$ of its environmental impacts. The stage contributes $84 \%$ for Type 1 (brick/block building), $94 \%$ for Type 2 (cladded timber building), 78\% for Type 3 (ICF building) and 85\% for Type 4 (steel building). This further buttresses the need for increased stringency of legal requirements that stipulate the use of renewable technology for buildings operation.

Table 3: Global Warming Potential of the typologies (measured in $\mathrm{KgCO}_{2}$ )

\begin{tabular}{|l|c|c|c|c|c|c|}
\hline \multirow{2}{*}{ Typologies } & \multicolumn{2}{|c|}{ Global Warming Potential per Lifecycle Stages (measured in $\mathrm{KgCO}_{2}$ ) } & $\begin{array}{c}\text { TOTAL } \\
\text { IMPACTS }\end{array}$ \\
\cline { 2 - 6 } & Product & Construction & Replacement & Operation & End of Life & IMP \\
\hline Type 1: Brick/block building & 716000 & 84400 & 3840 & 4380000 & 23200 & 5207440 \\
\hline Type 1A: Type 1 with PV panels & 727027 & 84400 & 3840 & 580000 & 23200 & 1418467 \\
\hline Type 2: Timber structure & 235500 & 26540 & 13745 & 4390000 & 6840 & 4672625 \\
\hline Type 2A: Type 2 with PV panels & 246527 & 26540 & 13745 & 596105 & 6840 & 889757 \\
\hline Type 3: Insulated Concrete Form & 1080900 & 128000 & 10424 & 4400000 & 50900 & 5670224 \\
\hline Type 3A: Type 3 with PV panels & 1091930 & 128000 & 10424 & 599871 & 50900 & 1881125 \\
\hline Type 4: Steel structured building & 659000 & 72800 & 83200 & 4540000 & 9760 & 5364760 \\
\hline Type 4A: Type 4 with PV panels & 670030 & 72800 & 83200 & 740320 & 9760 & 1576110 \\
\hline
\end{tabular}

Note: Type 1A, 2A, 3A and 4A are of the same materials as 1, 2, 3, and 4 respectively. However, they employed solar $P V$ panels for powering electricity, fans and miscellaneous equipment.

On the other hand, the lifecycle human health impact of the building typologies also range from one typology to another, with buildings employing renewable technology having lesser health impacts than those using fossil fuel (see table 4). Similarly, operational stage of the buildings have more health impacts than other stages of the building lifecycle. This suggests that the use of fossil fuel is not only having negative environmental impacts, it also affects human health as a result of its release of particulate matters capable of affecting respiratory system. As the buildings employ renewable technology (Type 1A, 2A, 3A and 4A), environmental and health impacts due to their operational stage significantly reduced, while there are non-significance increase in embodied impacts. Albeit small magnitude of the increment, it suggests that as buildings become energy efficient during their operational 
stage, embodied impacts need to be reduced. According to Ajayi et al. (2015b), this could be tackled by allocating eco-pints to different materials so that designers would be encouraged to specify environmental friendly materials for their designs.

Table 4: Lifecycle Health Impacts of the typologies (measured in KgPM2.5)

\begin{tabular}{|c|c|c|c|c|c|c|}
\hline \multirow{2}{*}{ Typologies } & \multicolumn{5}{|c|}{ Health Impacts per Lifecycle Stages (measured in KgPM2.5) } & \multirow{2}{*}{$\begin{array}{l}\text { TOTAL } \\
\text { IMPACTS }\end{array}$} \\
\hline & Product & Construction & Replacement & Operation & End of Life & \\
\hline Type 1: Brick/block building & 1465 & 72 & 7 & 4135 & 7 & 5686 \\
\hline Type 1A: Type 1 with PV panels & 1540 & 72 & 7 & 612 & 7 & 2238 \\
\hline Type 2: Timber structure & 26 & 26 & 46 & 4130 & 2 & 4230 \\
\hline Type 2A: Type 2 with PV panels & 101 & 26 & 46 & 607 & 2 & 782 \\
\hline Type 3: Insulated Concrete Form & 2993 & 109 & 26 & 4140 & 14 & 7282 \\
\hline Type 3A: Type 3 with PV panels & 3068 & 109 & 26 & 617 & 14 & 3834 \\
\hline Type 4: Steel structured building & 1201 & 37 & 188 & 4290 & 3 & 5719 \\
\hline Type 4A: Type 4 with PV panels & 1276 & 37 & 188 & 767 & 3 & 2271 \\
\hline
\end{tabular}

Note: Type 1A, 2A, 3A and 4A are of the same materials as 1, 2, 3, and 4 respectively. However, they employed solar $P V$ panels for powering electricity, fans and miscellaneous equipment.

\section{Global Warming Potential (GWP) of different typologies}

As evident in Figure 3, negative environmental impacts of the building typologies ranges from ICF building, steel building, brick/block building, timber building, ICF building (with PV panel), steel building (with PV panel), brick/block building (with PV panel) to timber building (with PV panel). This corresponds with types 3, 4, 1, 2, 3A, 4A, 1A and 2A respectively. It means that while building constructed with Insulated Concrete Forms (ICF building - type 3) has the highest negative environmental impacts, timber building (with PV panel - type 2A) is the most environmental friendly. With lifecycle emission of $5670224 \mathrm{KgCO} 2$, the ICF building has $\mathrm{CO}_{2}$ equivalent of 573SUVs over a 30 -year lifecycle or 19SUVs per year, while brick/block, steel and cladded timber building have $\mathrm{CO}_{2}$ equivalent of 17SUVs/year, 18SUVs/year and 16SUVs/year respectively. 


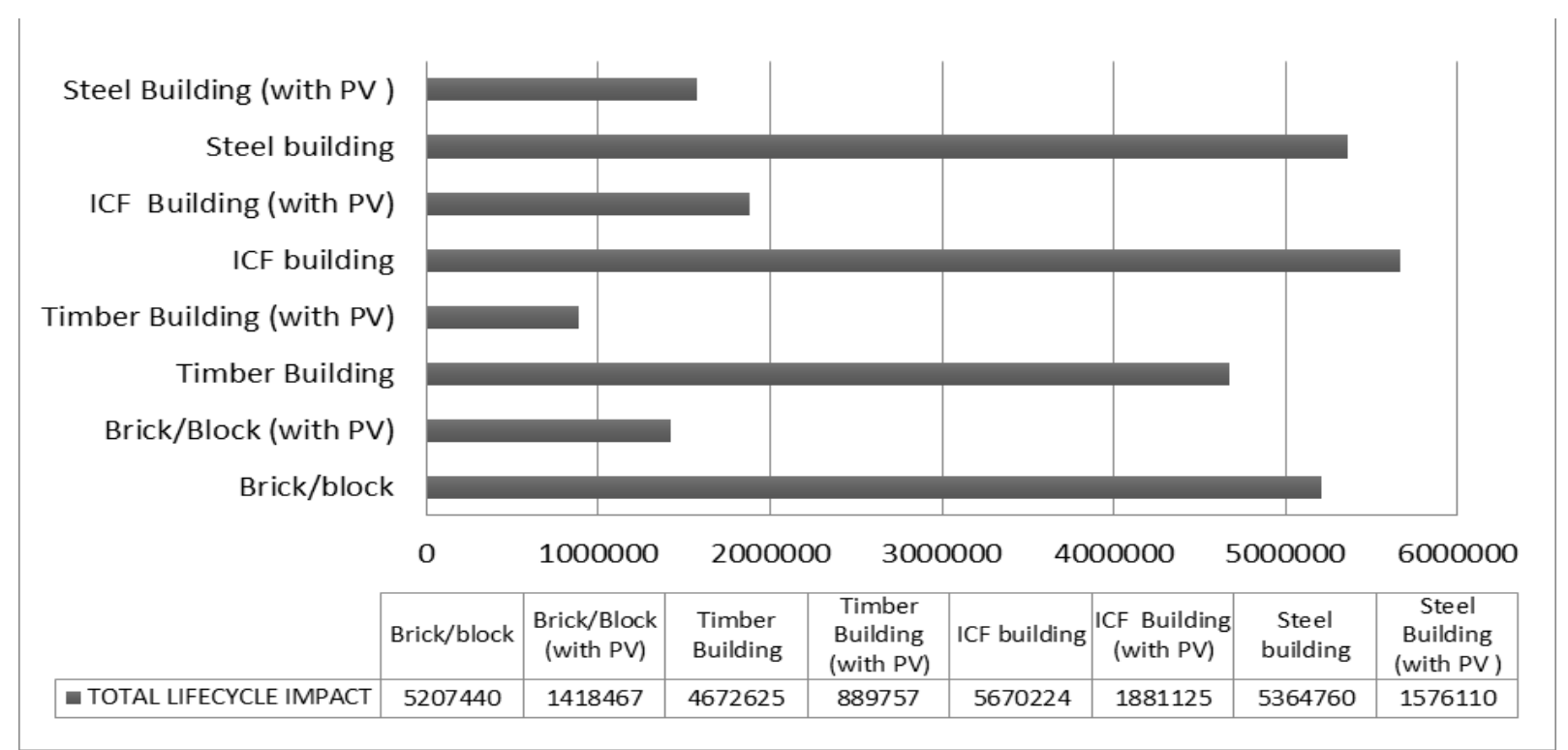

Figure 3: Lifecycle environmental impacts of the typologies (measured in $\mathrm{KgCO}$ ).

\section{Human Health Impacts of different typologies}

Figure 4 shows the distribution of health impacts of the different building typologies. From the figure, it is evident that the building constructed with ICF has the highest health impacts, while timber building has the least impacts on human health. Generally, the health impacts of the building typologies improve from types $3,4,1,2,3 \mathrm{~A}, 4 \mathrm{~A}, 1 \mathrm{~A}$ to $2 \mathrm{~A}$ in descending order.

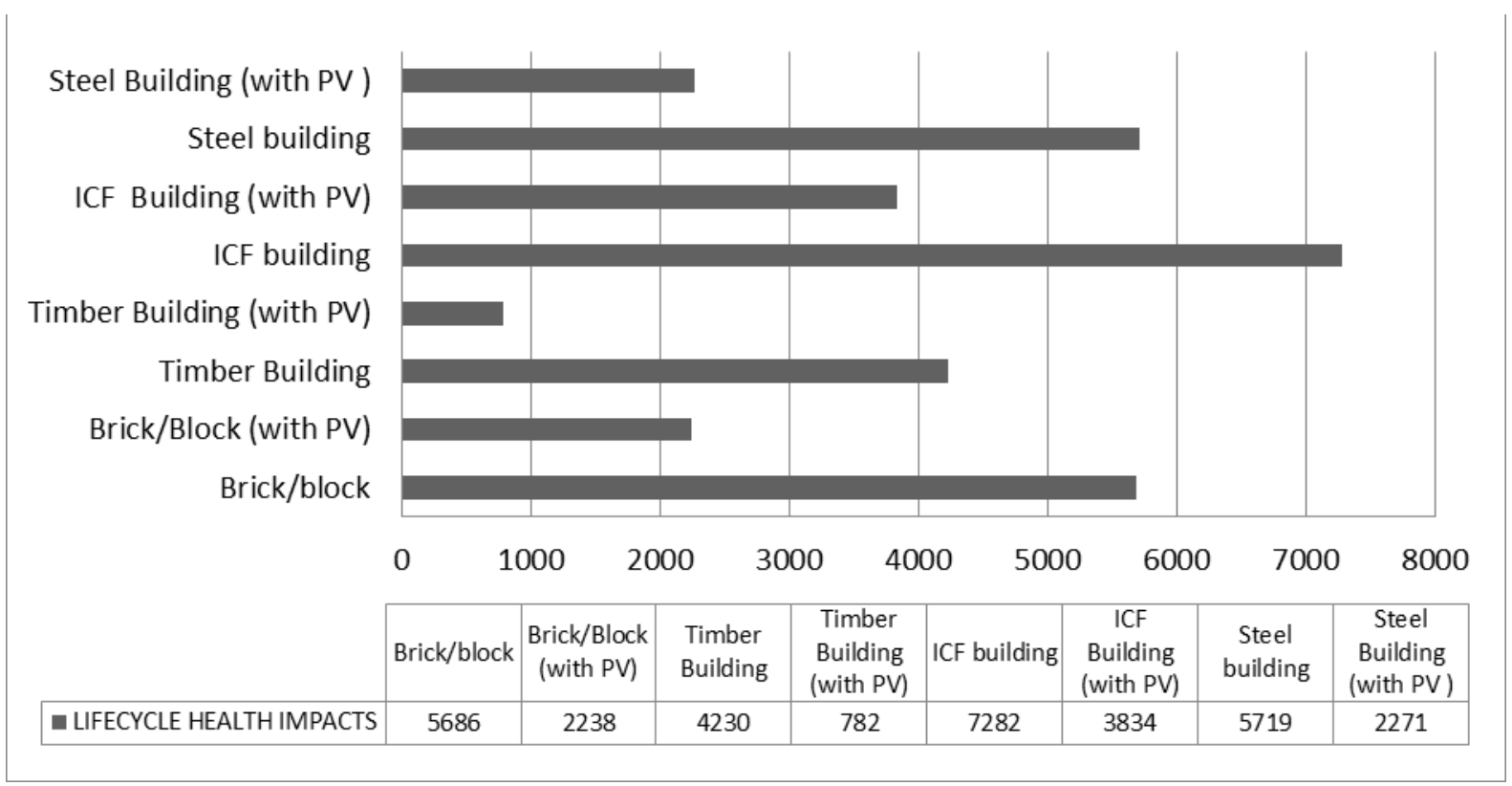

Figure 4: Lifecycle health impacts of the typologies (measured in KgPM2.5). 


\section{Relationship between Sustainability and Human Health Impacts}

A direct relationship is observed between global warming impacts of the buildings and their health impacts. As shown in Figure 5, the more the global warming potential of a building typology, the more its health impacts. This ranges equally for all the eight building typologies used in this study, thereby suggesting that by tackling environmental impacts of a building from sustainability perspective, negative health impact of such building has also been prevented. This was further clarified by Table 5, which shows the same ranking between GWP of the buildings and their human health impacts.

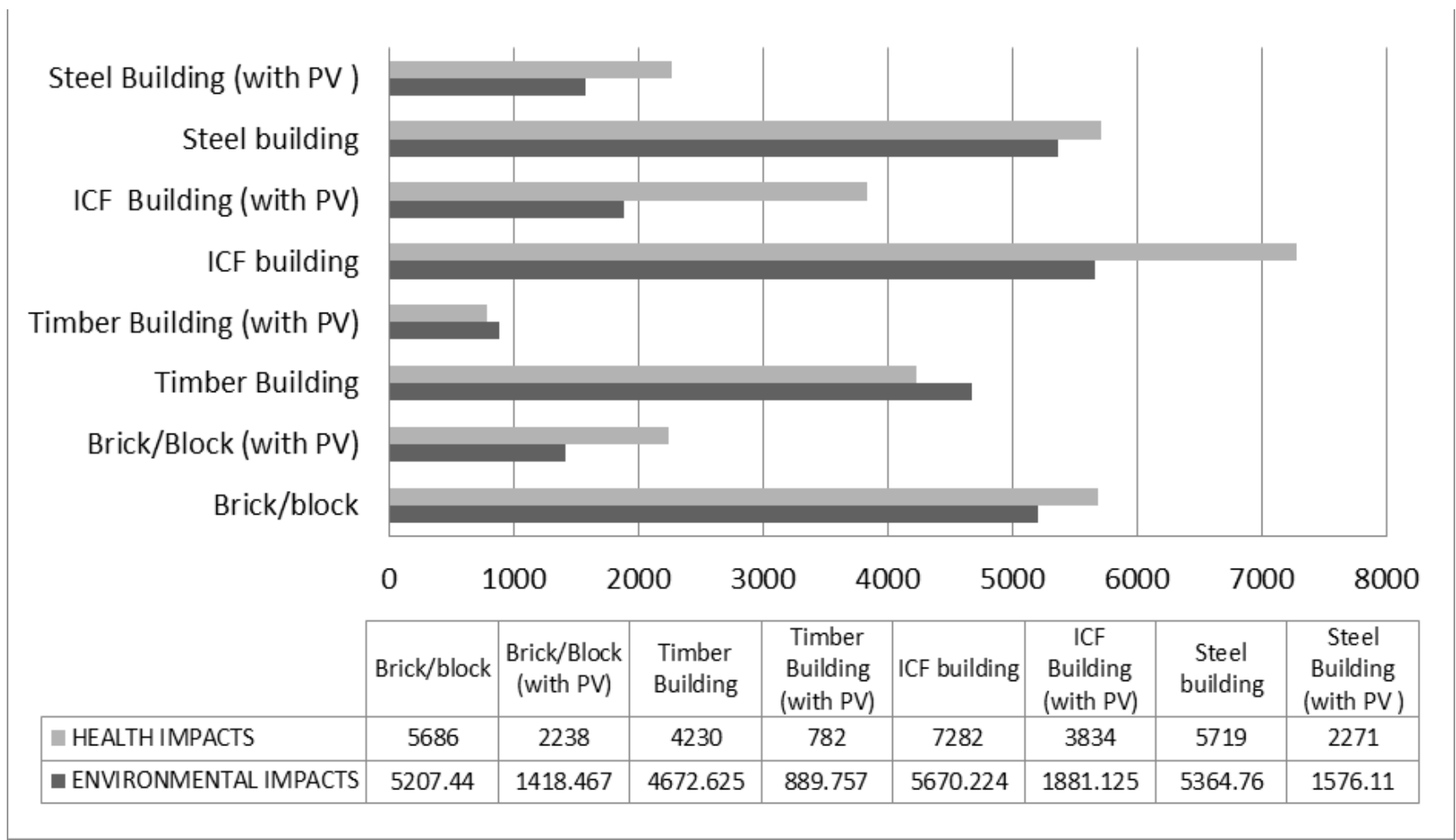

Figure 5: Comparison of health and environmental impacts of the eight typologies 
Table 5: Ranking of the lifecycle health impacts and GWP of the building typologies

\begin{tabular}{|l|c|c|c|c|}
\hline Building Typologies & $\begin{array}{c}\text { Lifecycle Health } \\
\text { Impacts }\end{array}$ & $\begin{array}{c}\text { Ranking of } \\
\text { Health Impacts }\end{array}$ & $\begin{array}{c}\text { Lifecycle } \\
\text { GWP }\end{array}$ & $\begin{array}{c}\text { Ranking of } \\
\text { the GWP }\end{array}$ \\
\hline Type 1: Brick/block building & 5686 & 6 & 5207440 & 6 \\
\hline Type 1A: Type 1 with PV panels & 2238 & 2 & 1418467 & 2 \\
\hline Type 2: Timber structure & 4230 & 5 & 4672625 & 5 \\
\hline Type 2A: Type 2 with PV panels & 782 & 1 & 889757 & 1 \\
\hline Type 3: Insulated Concrete Form & 7282 & 8 & 5670224 & 8 \\
\hline Type 3A: Type 3 with PV panels & 3834 & 4 & 1881125 & 4 \\
\hline Type 4: Steel structured building & 5719 & 7 & 5364760 & 7 \\
\hline Type 4A: Type 4 with PV panels & 2271 & 3 & 1576110 & 3 \\
\hline
\end{tabular}

Note: Type 1A, 2A, 3A and 4A are of the same materials as 1, 2, 3, and 4 respectively. However, they employed solar PV panels for powering electricity, fans and miscellaneous equipment.

As shown in Figure 5, the ICF building (Type 3) has the highest environmental and health impacts, this was followed by steel building, brick/block building and timber building respectively. The energy efficient alternatives for each typology also follow the same pattern. This means that for both environmental and health impacts of the eight typologies, the lifecycle impacts ranges from ICF building, steel building, brick/block building, timber building, ICF building (with PV panel), steel building (with PV panel), brick/block building (with PV panel) to timber building (with PV panel). This corresponds with types 3, 4, 1, 2, $3 \mathrm{~A}, 4 \mathrm{~A}, 1 \mathrm{~A}$ and $2 \mathrm{~A}$ respectively. This thus confirms the hypothesis that the more sustainable a building, the healthier it becomes.

\section{Conclusion}

The overall goal of this study was to determine the relationship between building sustainability and building health. Whole lifecycle environmental and health impacts of building were evaluated through the use of a case study of academic block. In order to enhance comparison of human health impacts and sustainability of the case study model, materials specification and energy use pattern were varied across eight typologies. The study suggests that operational stage of building lifecycle contributes the highest impacts over the building lifecycle. This confirms that buildings that are based on renewable technology during its operational stage are more sustainable and healthier than those that are based on fossil fuel. 
In terms of materials, buildings constructed with timber are found to be more sustainable and healthier than brick/block building, which is also better than steel buildings in terms of environmental and health impacts. Building constructed with ICF is the least sustainable of all materials typologies considered in the study. Importantly, the same pattern was observed in terms of healthiness and environmental friendliness of all the eight cases used in the study. As the global warming potentials and health impacts of the buildings are found to be precedential, precursory and contiguous, the study therefore confirms that the more sustainable a building, the healthier it becomes. Thus, by addressing sustainability of the built environment, negative health impacts of the buildings are also prevented.

This study has implications for practice. It implies that in order to prevent environmental health impacts of buildings, sustainable approach must be adopted. This is required in terms of materials use, construction technologies, building operations and end of life deconstruction of the buildings. Just as the use of renewable energy is important for building operation, low impacts materials should also be considered in building specification. This would mean that whole life impacts has been considered in the design. The result presented in this study has been limited to environmental health impacts of buildings, and should be interpreted as such. While the concept of SBS stressed the impacts of indoor environment, this study concentrated on particulate matters present in the air as a result of building activities that span from cradle to grave. Indoor healthiness of buildings is therefore beyond the scope of the study, as the study is limited to the wider environment As such, healthiness of building adjudged in this study has been due to its contribution of less particulate matters to the environment. Further study could therefore investigate the impacts of building materials specifications on occupants' well-being.

\section{References}

Adalberth K. (1997). Energy use during the life cycle of buildings: A method. Building and Environment, 32(4), pp. 317-320.

Ajayi, S.O., Oyedele, L.O., Alaka, H.A., Owolabi, H.A., Bilal, M., \& Akinade, O.O. (2014). Expository Study of Building Related health Issues: Need for Safety Measures. In: M. Okeil (Ed.). Smart, sustainable and healthy city, proceeding of the first international conference of the CIB Middle East and North Africa Research Network, CIB-MENA, Abu Dhabi, UAE; 12/2014, pp. 521 - 532.

Ajayi, S. O., Oyedele, L. O., Bilal, M., Akinade, O.O., Alaka, H.A., Owolabi, H.A., \& Kadiri, K.O., (2015a). Waste Effectiveness of the Construction Industry: Understanding 
the Impediments and Requisites for Improvement. Resource, Conservation and Recycling, 102(2015), $101-112$.

Ajayi, S. O., Oyedele, L. O., Ceranic, B., Gallanagh, M., \& Kadiri, K. O. (2015b). Life cycle environmental performance of material specification: a BIM-enhanced comparative assessment. International Journal of Sustainable Building Technology and Urban Development, 6(1), 14-24.

Akinade, O.O., Oyedele, L.O., Bilal, M., Ajayi, S.O., Owolabi, H.A., Alaka, H.A. and Bello, S.A., 2015. Waste minimisation through deconstruction: A BIM based Deconstructability Assessment Score (BIM-DAS). Resources, Conservation and Recycling, 105, pp.167-176.

Allen, J. G., MacNaughton, P., Laurent, J. G. C., Flanigan, S. S., Eitland, E. S., \& Spengler, J. D. (2014). Green Buildings and Health. Current Environmental Health Reports, 2(3), 250-258.

Anderson, J., \& Thornback, J. (2012). A guide to understanding the embodied impacts of construction products. London: CPA.

Anink, D., Mak, J., \& Boonstra, C. (1996). Handbook of sustainable building: An environmental preference method for selection of materials for use in construction and refurbishment. London: James and James.

ATHENA (2013). Athena Impact Estimator for Buildings: V 4.2 Software and Database Overview, Canada: Athena.

Baek, C., Park, S., Suzuki, M., \& Lee, S. (2013). Life cycle carbon dioxide assessment tool for buildings in the schematic design phase. Energy and Buildings, 61(2013), pp. 275287

Boldi, R. A. (2014). A comparison of the indoor and outdoor concentrations of fine particulate matter in various locations within Dubai, UAE. In: Okeil, M. (Ed). Smart, sustainable and healthy city, proceedings of the First International Conference of the CIB Middle East and North Africa Research Network (CIB-MENA 2014), December 14 $-16,2014$, pp. $511-520$.

Bornehag, C. G., Blomquist, G., Gyntelberg, F., Jarvholm, B., Malmberg, P., Nordvall, L., \& Sundell, J. (2001). Dampness in buildings and health. Indoor air, 11(2), 72-86.

Burge, S., Hedge, A., Wilson, S., Bass, J. H., \& Robertson, A. (1987). Sick building syndrome: A study of 4373 office workers. Annals of Occupational Hygiene, 31(4A), 493-504.

Chau, C. K., Yik, F. W. H., Hui, W. K., Liu, H. C., \& Yu, H. K. (2007). Environmental impacts of building materials and building services components for commercial buildings in Hong Kong. Journal of Cleaner Production, 15(18), 1840-1851.

Cheshire, D. (2011). Are green buildings healthy? The technical journal for AECOM's global Building Engineering services, Summer/Spring, 2011, pp. 10 - 15 
Cole, R. J. (1998). Charting the future: Emerging trends in building environmental assessment methods. Building Research and Information, 26(1), 3-16.

Ding, G. K. (2008). Sustainable construction-The role of environmental assessment tools. Journal of environmental management, 86(3), 451-464.

Dodoo, A., Gustavsson, L., \& Sathre, R. (2012). Lifecycle primary energy analysis of conventional and passive houses. International Journal of Sustainable Building Technology and Urban Development, 3(2), pp. 105-111.

Finnegan, M. J., Pickering, C. A., \& Burge, P. S. (1984). The sick building syndrome: Prevalence studies. BMJ, 289(6458), 1573-1575.

Gangolells, M., Casals, M., Gassó, S., Forcada, N., Roca, X., \& Fuertes, A. (2009). A methodology for predicting the severity of environmental impacts related to the construction process of residential buildings. Building and Environment, 44(3), 558571.

Ghattas, R., Gregory, J., Olivetti, E., \& Greene, S. (2013). Life cycle assessment for residential buildings: A literature review and gap analysis (online). Available from: http://web.mit.edu/cshub/news/pdf. [Accessed: May, 2013]

Guggemos, A. A., \& Horvath, A. (2005). Comparison of environmental effects of steel-and concrete-framed buildings. Journal of infrastructure systems, 11(2), 93-101.

Guidotti, T.L. (2015). Health and sustainability: An introduction. Oxford: Oxford University Press.

Gunnbjörnsdottir, M. I., Norbäck, D., Plaschke, P., Norrman, E., Björnsson, E., \& Janson, C. (2003). The relationship between indicators of building dampness and respiratory health in young Swedish adults. Respiratory medicine, 97(4), 302-307.

Hamilton, L., Edwards, S., Aizlewood, C., Shiers, D., Thistlethwaite, P., \& Steele, K. (2007). Creating environmental weightings for construction products. Bracknell: BRE Press

Hammond, G., \& Jones, C., (ed.) (2008). Inventory of Carbon and Energy (ICE), version 1.6a

Hood, E. (2005). Dwelling disparities: How poor housing leads to poor health. Environmental Health Perspectives, 113(5), pp. A310-A317.

Khasreen, M.M., Banfill, P.F.G. and Menzies, G.F., (2009). Life-Cycle Assessment and the Environmental Impact of Buildings: A Review. Sustainability 2009(1), 674-701.

Munasinghe, M. (2007). Sustainable development triangle. Available at: http://www. http://www.eoearth.org/view/article/156365/

Nemry, F., Uihlein, A., Colodel, C. M., Wetzel, C., Braune, A., Wittstock, B., ... \& Frech, Y. (2010). Options to reduce the environmental impacts of residential buildings in the European Union-Potential and costs. Energy and Buildings, 42(7), 976-984.

Ooteghem, K.V., \& Xu, L. (2012). The life-cycle assessment of a single-storey retail building in Canada. Building and Environment, 49(2012), pp. 212-226 
Optis, M., \& Wild, P. (2010). Inadequate documentation in published life cycle energy reports on buildings. The International Journal of Life Cycle Assessment, 15 (7), 644651.

Oyedele, L. O., Ajayi, S. O., \& Kadiri, K. O. (2014). Use of recycled products in UK construction industry: An empirical investigation into critical impediments and strategies for improvement. Resources, Conservation and Recycling, 93(2014), 23-31.

Perdue, W. C., Stone, L. A., \& Gostin, L. O. (2003). The built environment and its relationship to the public's health: The legal framework. American Journal of Public Health, 93(9), 1390-1394.

Poland, B., \& Dooris, M. (2010). A green and healthy future: The settings approach to building health. Critical Public Health, 20(3), 281-298.

Ramesh, T., Prakash, R., \& Shukla, K. K. (2010). Life cycle energy analysis of buildings: An overview. Energy and Buildings, 42 (2010), 1592-1600.

Raw, G.J., Aizlewood, C.E. \& Hamilton, R.M. (Eds.) (2001). Building regulations, health and safety. London: BRE.

Redlich, C. A., Sparer, J., \& Cullen, M. R. (1997). Sick-building syndrome. The Lancet, 349(9057), pp. 1013-1016.

Riley, W. J., McKone, T. E., Lai, A. C., \& Nazaroff, W. W. (2002). Indoor particulate matter of outdoor origin: Importance of size-dependent removal mechanisms. Environmental science \& technology, 36(2), 200-207.

Rossi, B., Marique, A.F., Glaumann, M., \& Reiter, S. (2012). Life-cycle assessment of residential buildings in three different European locations, basic tool. Building and Environment, 51(2012), 395 - 401.

Sartori, I., \& Hestnes, A. G. (2007). Energy use in the life cycle of conventional and lowenergy buildings: A review article. Energy and Buildings, 39(3), 249-257.

Säynäjoki, A., Heinonen, J., \& Junnila, S. (2012). A scenario analysis of the life cycle greenhouse gas emissions of a new residential area. Environmental Research Letters, 7(3), 034037.

Scheuer, C., Keoleian, G.A., \& Reppe, P. (2003). Life cycle energy and environmental performance of a new university building: modelling challenges and design implications. Energy and Buildings, 35 (10) pp. 1049-1064.

Sherwani, A.F., Usmani, J.A., \& Varun, (2010). Life cycle assessment of solar PV based electricity generation systems: A review. Renewable and Sustainable Energy Reviews, 14(1) pp. 540-544.

Singh, A., Syal, M., Grady, S. C., \& Korkmaz, S. (2010). Effects of green buildings on employee health and productivity. American journal of public health, 100(9), 1665.

Wang, E., Shen, Z., \& Barryman, C. (2011). A building LCA case study using Autodesk Ecotect and BIM model. Papers in construction management. Paper 6, University of Nebraska - Lincoln 
Zhong, Z.W., Song, B., \& Loh, P.E. (2011). LCAs of a polycrystalline photovoltaic module and a wind turbine. Renewable Energy, 36 (8), pp. 2227 - 2237. 